\title{
DIGITALCOMMONS
}

@WAYNESTATE-

Wayne State University

\section{Forced Technology Transfer and the US-China Trade War: Implications for International Economic Law}

Julia Ya Qin

Wayne State University

Follow this and additional works at: https://digitalcommons.wayne.edu/lawfrp

Part of the International Law Commons, and the International Trade Law Commons

\section{Recommended Citation}

Julia Ya Qin, Forced Technology Transfer and the US-China Trade War: Implications for International Economic Law, 22 J. Int'I Econ. L 743 (2019)

This Article is brought to you for free and open access by the Law School at DigitalCommons@WayneState. It has been accepted for inclusion in Law Faculty Research Publications by an authorized administrator of DigitalCommons@WayneState. 


\title{
Forced Technology Transfer and the US-China Trade War: Implications for International Economic Law
}

\author{
Julia Ya Qin*
}

\begin{abstract}
Forced technology transfer has emerged from the US-China trade war as a new issue of systemic importance. The USA, the European Union, and Japan have jointly condemned forced technology transfer as a practice undermining the proper function of international trade and called for new WTO rules to discipline the practice. This article examines the issue in the broad context of international economic law. It seeks to address the following questions: What does 'forced technology transfer' mean? Where did this practice come from? Why is there insufficient international regulation on the issue? What exactly are the problems inherent in such practice? And what can be done to improve the relevant international regulation?
\end{abstract}

\section{INTRODUCTION}

The US-China trade war was officially triggered by US allegations of China's unfair trade practices in technology transfer and intellectual property under Section 301 of the Trade Act of $1974 .{ }^{1}$ According to the USA, China, among other things, practices 'forced technology transfer' by using administrative processes and ownership restrictions to coerce US firms to transfer technology to Chinese entities. Based on these allegations, the Trump administration has resorted to unilateral actions under Section 301. Since July 2018, the USA has levied additional tariffs on more than half of Chinese imports; denying these allegations, China has retaliated in kind. ${ }^{2}$ At the time of writing, the trade

* Professor of Law, Wayne State University, U.S.A. I am grateful to Anne van Aaken, Chad Bown, Andrew Lang, Ruosi Zhang, Milan Hejtmanek, and two anonymous reviewers for their insightful comments on drafts of this article. Email: ya.qin@wayne.edu.

1 United States Trade Representatives, 'Findings of the Investigation into China's Acts, Policies and Practices Related to Technology Transfer, Intellectual Property and Innovation under Section 301 of the Trade Act of 1974', (22 March 2018) ('Section 301 Report'), https://ustr.gov/sites/default/files/Section\%20301 \%20FINAL.PDF.

2 For details of tariffs levied during the trade war, see Chad Bown and Malina Kolb, 'Trump's Trade War Timeline: An Up-to-Date Guide', https://www.piie.com/blogs/trade-investment-policy-watch/trumptrade-war-china-date-guide.

(C) The Author(s) 2019. Published by Oxford University Press. All rights reserved. For Permissions, please email: journals.permissions@oup.com 
war has further evolved into a technology war, with the USA imposing sanctions on top Chinese technology companies. ${ }^{3}$

Despite the apparent WTO-illegality of Section 301 tariffs, ${ }^{4}$ the USA has garnered support from the European Union and Japan specifically on the issue of forced technology transfer. The three parties have issued several joint statements, condemning forced technology transfer as a practice 'harmful to the development and use of innovative technologies' and 'undermining the proper functioning of international trade. ${ }^{5}$ Identifying forced technology transfer as 'a major trade irritant,' the EU has called for enacting new WTO rules to discipline the practice ${ }^{6}$ and has brought a WTO complaint against China on the issue. ${ }^{7}$ Forced technology transfer, therefore, has emerged for the first time as an issue of systemic importance for the world trade regime.

This article seeks to examine this issue in the context of international economic law. It has several goals. First, it seeks to clarify what 'forced technology transfer' means (Section I). Though widely used, the notion lacks a clear definition and is often misunderstood. Second, it traces the origin of 'forced technology transfer' in China to the 'market for technology' policy adopted in the early days of China's economic reform (Section II), and inquires whether this policy is a legitimate tool for economic development or an unfair trade practice (Section IV). Third, it examines existing international regulation on technology transfer and seeks to explain why such regulation does not effectively discipline 'forced technology transfer' (Section III). Lastly, the article proposes a way to establish a new multilateral discipline that can address the issue of 'forced technology transfer' equitably (Section V). The overall objective of this new discipline is to achieve a proper balance between the need to promote dissemination of technology and the need to ensure fair competition in international trade and investment.

\section{WHAT IS 'FORCED TECHNOLOGY TRANSFER'?}

Technology, broadly defined, ${ }^{8}$ can be disseminated from its originating source to other parties and places via various means. It may be disseminated through education, technological aid, employment, commercial transactions, or outright theft. More typically, cross-border transfers of technology are carried out through commercial transactions. Such a transaction may involve licensing, in which the transferor permits the transferee

3 US Department of Commerce has 'blacklisted' Huawei and several other Chinese tech companies for export control. See 84 FR 22961 (21 May 2019); 84 FR 29371 (24 June 2019). See also David Lynch, 'How the U.S.-China Trade War Became a Conflict over the Future of Tech', The Washington Post (22 May 2019).

4 The WTO provisions at issue include Articles 1 (MFN) and II (tariff bindings) of the General Agreement on Tariffs and Trade, and Article 23 of the Dispute Settlement Understanding. See China's WTO complaints, United States-Tariff Measures on Certain Goods from China, WT/DS543/1, 5 April 2018; United States-Tariff Measures on Certain Goods from China II, WT/DS565/1, 27 August 2018.

5 See e.g. Joint Statement on Trilateral Meeting of the Trade Ministers of the United States, Japan and the European Union, Annexed Statement 2: Joint Statement on Technology Transfer Policies and Practices, (31 May 2018).

6 The European Commission, WTO-EU's Proposals on WTO Modernization (5 July 2018) ('The EU Concept Paper'), http://src.bna.com/Aoe.

7 See China - Certain Measures on the Transfer of Technology, Request for Consultations By the European Union, WT/DS549/1/Rev. 1, 8 January 2019.

8 Technology is defined to include all information protected by patents, trademarks, copyrights, trade secrets, technical know-how and other types of intellectual property protections. Section 301 Report, Box I.1. 
to use its technology for a certain period of time, or a sale in which the transferor assigns its ownership of the technology to the transferee, or an investment in which the transferor contributes its technology as equity investment in the transferee.

In spite of its wide use, the term 'forced technology transfer' has not been well defined. ${ }^{9}$ The term defies an easy definition because what constitutes, or is perceived as, a 'forced' transfer depends not only on the degree of compulsion imposed by a particular government policy but also on the specific conditions of the firm affected thereby. The situation can be further complicated when the government policy is implemented via implicit means. ${ }^{10}$

For the purpose of this article, I will use the term generally to refer to any situation in which the government requires a foreign firm to share its proprietary information in order to conduct business in the country. ${ }^{11}$ Based on their implications for international economic law and policies, I will draw a distinction between two types of situations: (i) where the transfer is the result of disclosure of proprietary information compelled by administrative processes; and (ii) where the transfer is the result of ownership restrictions on foreign investment, such as mandatory joint venture (JV) requirements.

\section{A. Disclosure of proprietary information compelled by administrative processes}

A foreign firm may be required to disclose its proprietary information through a variety of administrative processes in order to obtain or maintain market access. In doing business with China, foreign firms are subject to a myriad of administrative requirements, ranging from approvals of specific investments, to various licensing requirements, to approvals of specific products, to regulatory compliance in antitrust investigations and national security reviews. In this regard, the most serious allegations are that, through these administrative processes, Chinese government agencies have forced foreign firms to disclose sensitive technical information, including proprietary formulas or designs, source code, databases, and trade secrets that are unnecessary for any legitimate regulatory purpose. ${ }^{12}$ For firms that have already made initial investments in the country, refusal to comply with government requests for information would be a recipe for losing their investments and likely access to the entire Chinese market. Under such circumstances, the firms would have 'no choice' but to comply with the government requests. The proprietary information so disclosed in the administrative processes could then be passed onto competing domestic entities.

9 The EU describes 'forced technology transfer' to mean 'where foreign operators are directly or indirectly forced to share their innovation and technology with the state or with domestic operators.' The EU Concept Paper, supra note 6.

10 See Dan Prud'homme et al., 'Forced Technology Transfer' Policies: Workings in China and Strategic Implications', 134 Technological Forecasting and Social Change 150-68 (2018); OECD, International Technology Transfer Policies, TAD/TC/WP (2018)8/Final, 14 January 2019 (describing a spectrum of government policies that can cause a firm to transfer proprietary technologies).

11 In contrast, the USTR has used the term to encompass China's overseas acquisitions of US companies with cutting-edge technologies and cyber theft. See USTR, 2018 Report to Congress on China's WTO Compliance (February 2019), p. 17.

12 Section 301 Report, pp. 41-43. See also B. Davis, 'How China Systematically Pries Technology From U.S. Companies', Wall Street Journal, 26 September 2018. 
These alleged administrative practices would amount to disguised government expropriation of foreign intellectual property rights, in violation of generally accepted international principles. Such practices would also violate the Agreement on TradeRelated Aspects of Intellectual Property Rights (TRIPS), under which China is obligated to protect undisclosed information submitted to the government agencies against unfair competition and unfair commercial use. ${ }^{13}$ Furthermore, requiring foreign firms to disclose proprietary information in connection with the administrative approval processes would run afoul of China's specific WTO commitments not to condition approvals of foreign investment on the transfer of technology. ${ }^{14}$ Thus, while the allegations may be difficult to prove in practice, it is uncontroversial that any disguised expropriation of foreign IP must be condemned. Indeed, in an apparent effort to address foreign concerns and to reaffirm its WTO commitments, China has adopted provisions in its new Foreign Investment Law that explicitly prohibit administrative organs and their staff from disclosing or illegally providing others the trade secrets of foreign investors that become known to them during their performance of duties. $^{15}$

\section{B. Ownership restrictions on foreign investment}

Ownership limitation on foreign investment is said to be one of the 'most important sources' of the problem of forced technology transfer. ${ }^{16}$ Compared to forced disclosure of propriety information, the allegation of forced technology transfer via ownership restrictions raises a more complex set of issues. First, there is no general principle of international law prohibiting governments from imposing ownership restrictions on foreign investment. Thus, China is not generally prevented from limiting foreign ownership except where it has made specific treaty commitments, such as in the service sectors under GATS and in the automotive industry under its WTO accession protocol. ${ }^{17}$

Second, forced technology transfer in this context is not 'free transfer'. In the case of technology being contributed as an equity investment, the value of the technology will be assessed as part of the foreign equity. In the case of technology being licensed to a JV, the foreign investor will receive licensing fees from the JV, the amount of which is subject to negotiation. ${ }^{18}$ According to one study, China ranks fourth globally in 2016 (after Ireland, the Netherlands and the USA) in the total amount paid for

13 TRIPS, art. 39.

14 See supra text, at note 66.

15 PRC Foreign Investment Law, arts 23 and 39 (effective 1 January 2020). A similar provision in existing law applies more narrowly to government employees in the administration of technology import. See PRC Regulation on the Administration of Import and Export of Technologies (2002), art. 23.

16 The EU Concept Paper, supra note 6.

17 See China's GATS Schedule (mode 3); Report of the Working Party on the Accession of China, $\mathrm{WT} / \mathrm{MIN}(01) / 3,10$ November 2001 ('WPR'), paras 204-07.

18 This does not mean the commercial terms of a technology transfer will not be subject to government regulation. On the contrary, the government may impose restrictions on all aspects of technology transfer, including the price and other terms of a licensing agreement. 
foreign IP. ${ }^{19}$ Hence, the case of 'forced technology transfer' via ownership restrictions must be distinguished from government expropriation or compulsory licensing, where the government may compel the transfer of technology without the consent of the technology owner and adequate compensation. ${ }^{20}$

Third, the transfer of technology may be compelled by foreign ownership restrictions in different ways. One is via mandatory JV requirements. If certain technology is necessary for the JV operation, the foreign owner will have no choice but to share it with its domestic partner, which may subsequently become a competitor. By comparison, the foreign investor in a wholly foreign-owned enterprise (WFOE) will have sole control over its operation, thus is less exposed to the risk of losing key technology to its competitors. ${ }^{21}$ Furthermore, in the JV negotiations the Chinese party may be under government pressure to demand technologies that the foreign party would not otherwise be willing to provide. Because mandatory JVs must be approved by the government, it is practically impossible to tell whether the demand for technology is attributable to government pressure or stems entirely from the Chinese party involved. Besides the JV requirement, the transfer of technology may be compelled as a result of an outright ban of foreign investment in specific sectors. A prominent example in this regard is cloud computing. According to US and EU complaints, China effectively precludes foreign cloud service providers from directly participating in the most common forms of cloud computing. ${ }^{22}$ For the US and EU cloud service providers, foregoing the China market is simply not a commercially viable option because their customers demand cloud services which, by nature, must be made globally available. Consequently, they have no choice but to enter into contractual arrangements with Chinese entities eligible to provide such services and to transfer their proprietary cloud computing technologies to the Chinese entities in exchange for a fee or a share of the revenue. ${ }^{23}$

\section{Insufficient enforcement $v$. insufficient regulation}

In thinking about how international economic law should respond to the two types of situations identified above, it is important to distinguish the case of insufficient enforcement from that of insufficient regulation. For disclosure of proprietary information compelled by administrative processes that constitutes 'disguised government expropriation', the basic legal principles are clear. While further elaboration of these principles through more specific rules may be desirable, the chief problem lies in the lack of enforcement of existing law. For technology transfer via ownership restrictions, on the other hand, the picture is a mixed one. To the extent that ownership restrictions do not contravene any obligation under the WTO or investment agreements, and that the

19 Nicholas Lardy, 'China: Forced Technology Transfer and Theft?', Peterson Institute of International Economics, China Economic Watch blog (20 April 2018) (based on IMF data).

20 Under TRIPS art. 31, compulsory licensing is permitted but subject to certain conditions, including the payment of 'adequate remuneration' to the right-holder.

21 Section 301 Report, p. 28. But the technology transferred to a WFOE may still 'leak' through its employees who leave the WFOE to join a competitor or start their own competing firms.

22 Section 301 Report, pp. 40-41; European Chamber of Commerce in China, China Manufacturing 2025, pp. 24-26 (2017).

23 Id. 
transfer of technology is the unavoidable consequence of local operations (such as comanagement and the hiring of local employees in a JV) or of contractual arrangements to overcome the ownership restrictions, it is a matter of insufficient or inadequate regulation. To the extent that the government uses ownership restrictions to evade its treaty obligations, such as the alleged government practice of demanding technology transfer through a Chinese JV partner, it is a problem of enforcement against evasion of existing WTO obligations.

The problem of insufficient enforcement of WTO law looms large in light of China's explicit WTO commitments not to compel technology transfer. According to the USA, China uses indirect and implicit means, such as oral instructions, to coerce technology transfer, which do not leave a paper trail and hence are 'almost impossible to prosecute. ${ }^{24}$ And this difficulty is further exacerbated by the reality that few foreign firms are willing to testify on record for fear of Chinese government retaliation, even though a significant number of them have reported receiving such pressure in confidential industry surveys. ${ }^{25}$ The lack of regulatory transparency, the complex relationship between the State and the private sector, and concerns about retaliation have been identified as the key elements that have enabled China's practices to persist. ${ }^{26}$ Apparently, it is the challenge of proving implicit government actions that has stopped the USA from bringing a WTO complaint on the issue of forced technology transfer. Meanwhile, China has categorically denied any wrongdoing, claiming that the Section 301 Report does not contain any 'solid evidence that could demonstrate that the Chinese government actually forced foreign companies to transfer technology. ${ }^{27}$

In the end, however, the challenge of proving the case of implicit government actions can only be met by taking China to the WTO dispute settlement forum. The key issues in such WTO litigation will be the standard of proof and attribution. As a general rule, WTO panels enjoy wide latitude in admitting and evaluating evidence of any kind and in deciding what weight to ascribe to each particular piece of evidence. ${ }^{28}$ In practice, unwritten measures have been successfully challenged under WTO law, based primarily on evidence from secondary sources, such as industry surveys, media reports, and policy statements of government officials. ${ }^{29}$ As for attribution, it should not be an issue in the case of forced disclosure of proprietary information in administrative processes, since it is clearly the government that has requested the information. Attribution would be an issue in the case of technology transfer demanded by a local JV partner, as the

24 Section 301 Report, p. 21.

25 Id., pp. 22-23 (citing member surveys conducted by the US-China Business Council and the American Chamber of Commerce in China).

26 Id., p. 21.

27 Statement by Ambassador Dr Zhang Xiangchen at the WTO DSB meeting on 28 May 2018, http://wto2. mofcom.gov.cn/article/chinaviewpoins/201805/20180502749669.shtml.

28 Panel Report, US - Antidumping Measures on Certain Hot-Rolled Steel Products from Japan, WT/DS184/R, 28 February 2001, para 7.10 (citing Appellate Body Report in US - Shrimp, paras 104-06). See generally Graham Cook, 'Defining the Standard of Proof in WTO Dispute Settlement Proceedings: Jurists' Prudence and Jurisprudence', 1 Journal of International Trade and Arbitration Law 50 (2012) (suggesting that the WTO standard of proof is one of the 'balance of probabilities').

29 Appellate Body Report, Argentina - Measures Affecting the Importation of Goods, WT/DS438, 444, 445/AB/R, 15 January 2015. 
complainant must prove that the JV partner's action is attributable to the government. But there are some well-established criteria for attributing the conduct of private parties to the government under WTO law. ${ }^{30}$ Without actual WTO litigation, however, it will not be possible to determine whether the WTO tribunal is able to apply proper standard of proof and attribution rules to address the particular situation in China. It is therefore regrettable that the USA has forgone WTO litigation to enforce China's explicit commitments on technology transfer, ${ }^{31}$ especially in light of Beijing's willingness to date to comply with adverse WTO rulings. ${ }^{32}$

The present study aims at tackling the problem of insufficient regulation, rather than insufficient enforcement of existing law. Given that ownership restrictions on foreign investment are neither generally prohibited by international law nor fully regulated by WTO specific disciplines, forced technology transfer in this context will be the main focus of the study. The issue, however, will need to be examined against the broader context of existing international regulation on technology transfer.

\section{FORCED TECHNOLOGY TRANSFER: ORIGIN, EVOLUTION, AND EFFECT}

Forced technology transfer has its origin in the 'market for technology' policy developed in the early days of China's economic reform. When it first opened up to foreign direct investment (FDI), China had a central-planned economy. Under the initial plan, foreign invested enterprises (FIEs) would sell all their products abroad, so that China could gain access to international markets and earn much-needed foreign exchange, on the one hand, and protect its domestic producers from foreign competition, on the other. Yet, considering the interests of foreign investors in selling to the Chinese market, the government would grant limited market access to the investors who were willing and able to bring advanced technologies to China. That FIEs should 'either export or utilize advanced technology' was the original version of China's market-for-technology policy. This policy was explicitly adopted by the foreign investment laws. ${ }^{33}$ To ensure that its foreign exchange would be well spent, the government also mandated that all technologies brought to China must be 'advanced' and all technology import contracts be separately reviewed and approved by government agencies. ${ }^{34}$

30 GATT Panel Report, Japan - Semi-Conductors (adopted 4May 1988), L/6309-35S/116, paras 108-17. See generally Geraldo Vidigal, 'Attribution in the WTO: The Limits of 'Sufficient Government Involvement', 6 (Special Issue) Journal of International Trade and Arbitration Law 133-160 (2017).

31 See Jennifer Hillman, The Best Way to Address China's Unfair Policies and Practices is Through a Big, Bold Multilateral Case at the WTO, testimony at Hearing on U.S. Tools to Address Chinese Market Distortions, U.S.-China Economic and Security Review Commission, 8 June 2018.

32 See generally Weihuan Zhou, China's Implementation of the Rulings of the World Trade Organization (Oxford: Hart Publishing, 2019).

33 See e.g. PRC Law on Foreign-Invested Enterprises (1986), art. 3. FIEs that were 'export-oriented' or 'utilizing advanced technology' also received preferential treatment from the government. See Provisions of the State Council on the Encouragement of Foreign Investment (11 October 1986).

34 PRC Regulation on Administration of Technology Import Contracts (1985), arts 3 and 4. 
China's WTO accession in 2001 prompted a major revamp of its FDI laws and policies. $^{35}$

To comply with the WTO Agreement on Trade-Related Investment Measures (TRIMS), China removed the mandatory requirements on export performance, local content, and foreign exchange balancing. More significantly, because China made a special WTO commitment not to condition the approval of foreign investment on 'the transfer of technology' or 'the conduct of research and development in China,' ${ }^{36}$ it also removed the requirement that FIEs import advanced technologies. Furthermore, following its WTO accession, technology import contracts no longer require government approvals unless the subject technology is on the list of restricted technologies. $^{37}$

However, removing the 'market-for-technology' types of requirements from the rulebook does not mean the elimination of such requirements in practice. In fact, the old policy can still be easily implemented, given that foreign investment remains subject to equity restrictions and specific government approvals. Moreover, the industry catalogue China uses to guide FDI has continued to divide investment projects into the categories of encouraged, permitted, restricted, and prohibited, with the encouraged category covering projects 'utilizing new and advanced technologies' and the restricted category covering projects deemed 'technologically lagging behind. ${ }^{\text {'3 }}$

China's FDI regime, however, will change dramatically when its new Foreign Investment Law takes effect on 1 January 2020. Under the new Law, except for sectors identified on the negative list, ${ }^{39}$ foreign investment projects will no longer require government approval, thus reversing a basic FDI policy of forty years. The new Law also explicitly prohibits government agencies and their staff from 'using administrative means to force the transfer of technology. 40 The reference to 'forced technology transfer' is the first in Chinese legislation. It can be viewed as a gesture of compromise in the trade war, considering that Beijing has never admitted the existence of the problem. ${ }^{41}$

On the whole, the market-for-technology policy appears to have worked successfully. When the policy was first adopted some thirty years ago, China was 'a horse-and-cart economy' without even a basic IP infrastructure. ${ }^{42}$ Today, the country has turned into a

35 See generally Julia Ya Qin, 'Trade, Investment and Beyond: The Impact of WTO Accession on China's Legal System', 191 (Special Issue) The China Quarterly 720-741 (2007).

36 WTO, Protocol on the Accession of the People's Republic of China, WT/L/432, 10 November 2001, Section 7(3).

37 PRC Regulation on Import and Export of Technologies, State Council Decree No. 331 (10 December 2001), effective 1 January 2002.

38 State Council, Provisions Guiding the Direction of Foreign Direct Investment, Order No. 346 (2002); NDRC and MOFCOM, Catalogue of Industries for Guiding Foreign Investment (2017 Revision).

39 Foreign Investment Law, supra note 15 . The latest negative list contains 40 sectors and sub-sectors in which foreign investment is restricted. See NDRC and MOFCOM, Special Management Measures for the Market Entry of Foreign Investment (Negative List) (2019 Version), effective 30 July 2019.

40 Foreign Investment Law, supra note 15, art. 22.

41 See State Council Information Office, China's Position on the China-US Economic and Trade Consultations (June 2019) (stating the accusation of forced technology transfer is 'utterly unfounded').

42 David Dodwell, 'China is on the Path to Global Technology Dominance', South China Morning Post, 24 March 2017. 
technology powerhouse, rivaling with the USA, Europe, and Japan in fields ranging from high-speed rail, to space, mobile communications, and artificial intelligence. This dramatic transformation can be attributed to many factors, but the market-for-technology policy has played an important role. China's vast and fast-growing market has attracted every multinational corporation to it. When faced with the demand that sales to China be accompanied by local manufacturing and technology transfer, foreign firms are often obliged to accept, given their need for revenue growth. These circumstances, for example, are said to have sowed the seeds for China's eventual success in $5 \mathrm{G}$ networks. ${ }^{43}$

However, the policy has not proven successful in every sector. A well-known example is the automotive sector. To develop its own auto industry, China has imposed a 50/50 $\mathrm{JV}$ requirement for foreign investment in the manufacturing of automobiles. Attracted by the potential Chinese market, every major auto company has formed such JVs with Chinese firms (typically state-owned). Today, China is the largest manufacturer as well as the largest consumer market for automobiles. Yet, the country has not produced a single name-brand vehicle of its own. Apparently, foreign auto companies have refrained from transferring key technologies to the Chinese, while earning hefty profits and royalties in a prosperous market. ${ }^{44}$

By contrast, the high-speed rail industry exemplifies the policy's success. China's railway industry is completely owned and controlled by the state. In order to develop high-speed rail, the Ministry of Railways tendered bids to foreign firms, requiring the foreign bidders to form JVs with two government-owned entities and transfer technology to the JVs. The handful industry leaders-Siemens, Alstom, Bombardier, and Kawasaki-all competed to win the bids for access to the world's largest railway market. This enabled China to acquire the most advanced technologies at low cost. Within a decade thereafter, the Chinese had mastered and improved the technologies and became the biggest player in the global market. ${ }^{45}$

Judging from these examples, the impact of the market-for-technology policy may depend on the market structure of a specific industry. Where there is limited competition, as in the railway industry, the policy is likely to succeed; where there is sufficient competition, as in the auto sector, foreign investors may better withstand the pressure for transferring their core technologies. ${ }^{46}$ In addition, it should be noted that, compared to equity restrictions, the requirement of local manufacturing - a practice apparently

43 Kiran Stacey, 'Why is There No US Rival to Compete with Huawei', Financial Times, 26 April 2019.

44 See Jane Cai and Keegan Elmer, 'Is the US right to cry foul about forced technology transfer to do business in China-and What is Beijing's Position?', South China Morning Post, 10 January 2019; Anjani Travedi, 'Behind the Myth of China's Great Technology Grab: The Issue of Forced Transfers is Overstated. Carmakers Know How to Safeguard Their Most Advanced Know-how', Bloomberg, 22 December 2018.

45 See Zhenhua Chen and Kingsley Haynes, 'A Short History of Technology Transfer and Capture: High Speed Rail in China' (2016), https://papers.ssrn.com/sol3/papers.cfm?abstract_id=2872527; Rongfang Liu et al., 'High Speed Rail Development in China: A Case Study of State-Guided Technology Transfer', Oxford Scholarship Online (2016), https://www.oxfordscholarship.com/view/10.1093/acprof:oso/ 9780198753568.001.0001/acprof-9780198753568-chapter-6.

46 See Liu et al., id. (comparing the high-speed rail industry, which has only a handful of manufacturers from four countries, with the automobile industry, which is present in many countries). 
inconsistent with the TRIMS Agreement-may have played an even greater role in the dissemination of technology to China. ${ }^{47}$

\section{INTERNATIONAL REGULATION OF TECHNOLOGY TRANSFER}

There is no generally applicable international agreement on technology transfer. Given that technology owners are private actors, it is difficult to regulate their behavior effectively through international disciplines. Attesting to such difficulties were the decade-long efforts (1976-85) to conclude a multilateral agreement within the United Nations - the International Code of Conduct for the Transfer of Technology. ${ }^{48}$ Driven by the demand of developing countries to increase the flow of technology from developed countries, the Code enacted principles of fair and equitable dealings and other norms to strengthen the position of technology-acquiring countries vis-à-vis technology suppliers. The draft Code, however, was never adopted, thanks to the NorthSouth divide on the desirability of such an instrument. ${ }^{49}$ The trend of international rulemaking has since shifted to strengthening the position of technology suppliers. Most significantly, the conclusion of the TRIPS Agreement has made the protection of IP rights enforceable through WTO dispute settlement. And a number of free trade and investment agreements have outlawed mandatory technology transfer. ${ }^{50}$

\section{A. Investment agreements}

Requiring foreign investors to transfer technology is known as one type of 'performance requirements' imposed by the host country on foreign investors. Performance requirements have been widely used, especially by developing countries, as a tool to manage FDI for achieving certain policy objectives. Examples of commonly used performance requirements include purchasing a certain level of local products, exporting a certain level of locally produced products, achieving a specific level of local jobs, transferring technology to the country, conducting research activities in the country, taking specific environmental and social actions, and forming JVs with local partners. ${ }^{51}$

Despite their wide use, performance requirements remain controversial. Proponents see them as a useful tool to maximize the benefit of FDI for local development, whereas critics view them as ineffective or even counterproductive. The latter view is reflected in the restriction of performance requirements under investment agreements and the WTO TRIMS. $^{52}$

47 See Steve Dickenson, 'China's New Foreign Investment Law and Forced Technology Transfer: Same as It Ever Was', China Law Blog (29 March 2019), https://www.chinalawblog.com/?s=forced+manufactur.

48 UNCTAD, Draft International Code of Conduct on the Transfer of Technology as of 5 June 1985, TD/CODE/TECHNOLOGY TRANSFER/47, 1985.

49 P.G. Sampath and P. Roffe, 'Unpacking the International Technology Transfer Debate: Fifty Years and Beyond', ICTSD Working Paper (June 2012) 25-28.

50 See generally Jonathan Bonnitcha, 'Investment Wars: Contestation and Confusion in Debate about Investment,' 22 (4) Journal of International Economic Law (forthcoming), section 3.

51 S. N. Nikiema, 'Performance Requirements in Investment Treaties', IISD (2014) 2-3, http://www.iisd.org/ sites/default/files/publications/best-practices-performance-requirements-investment-treaties-en.pdf.

52 Id., at 1. 
The North American Free Trade Agreement (NAFTA) is the first treaty to restrict performance requirements. Its investment chapter prohibits seven types of performance requirements, including the requirement to 'transfer technology, a production process or other proprietary knowledge' to a person in the host country, in connection with the establishment or operation of foreign investment. ${ }^{53}$ Similar clauses have since entered all free trade agreements (FTAs) negotiated by the USA, ${ }^{54}$ as well as the US Model Bilateral Investment Treaty (BIT) ${ }^{55}$ A number of non-US FTAs have also restricted performance requirements, including those concluded by Canada, EU, Japan, Australia, Singapore, and South Korea that specifically prohibit the requirement of technology transfer. ${ }^{56}$ More significantly, the largest multilateral FTA to date-the Comprehensive and Progressive Agreement for Trans-Pacific Partnership (CPTPP) contains elaborate provisions on performance requirements, including a broad restriction on the requirement of technology transfer. ${ }^{57}$

Interestingly, although JV requirement typically results in the transfer of technology to local entities, none of the investment agreements have categorized mandatory JV as one of the performance requirements to be eliminated. Rather, equity restrictions on foreign investment have been treated as a matter of market access, subject to negotiated extent of national treatment. Under NAFTA, for example, Mexico is obligated to grant national treatment to US and Canadian investors with respect to the establishment and acquisitions in Mexico. ${ }^{58}$ The obligation, however, is subject to specific exceptions. Thus, Mexico was able to maintain equity restriction on foreign investment in various sectors, such as the $49 \%$ ceiling in aviation. ${ }^{59}$

\section{B. Technology transfer under WTO Law}

Technology transfer is not a subject directly regulated by WTO rules. ${ }^{60}$ The handful of references to the term in the WTO multilateral agreements all concern encouragement of technology transfer, especially from developed countries to developing countries. The only exceptions are the China-specific rules under its accession protocol and certain implicit disciplines under GATS mode 3.

\section{TRIPS}

The TRIPS Agreement affects cross-border technology transfer by strengthening IP rights of technology owners but is silent on the issue of mandatory technology transfer. Article 7 (Objectives) states that the protection and enforcement of IP rights should

53 NAFTA, art. 1106(f).

54 See https://ustr.gov/trade-agreements/free-trade-agreements.

55 The 2012 US Model Bilateral Investment Treaty, art. 8.

56 Source: UNCTAD, International Investment Agreements Navigator, https://investmentpolicy.unctad.org/ international-investment-agreements; OECD, supra note 10, Table A1.

57 CPTPP, art. 9.10. СРTPP was concluded among 11 countries (Australia, Brunei, Canada, Chile, Japan, Malaysia, Mexico, New Zealand, Peru, Singapore, and Vietnam) and took effect in January 2019.

58 NAFTA, art. 1102.

59 US Department of State, 2017 Investment Climate Statements: Mexico, https://www.state.gov/reports/2017investment-climate-statements/mexico/.

60 See generally Bernard M. Hoekman, Keith E. Maskus and Kamal Saggi, 'Transfer of Technology to Developing Countries: Unilateral and Multilateral Policy Options’, 33 (10) World Development 1587-1602 (2005). 
contribute' to the transfer and dissemination of technology. Article 8.2 (Principles) recognizes that WTO members may need to adopt appropriate measures to prevent practices that 'adversely affect the international transfer of technology.' Notably, Article 66.2 (Least-Developed Country Members) mandates that developed country members 'shall provide incentives' to their enterprises and institutions for the purpose of 'promoting and encouraging technology transfer' to least-developed country members, although how the mandate should be implemented remains unclear.

\section{TRIMS}

The TRIMS Agreement is one of the two WTO agreements that address investment issues (the other being GATS). It focuses on 'trade-related' performance requirements, prohibiting measures that are considered inconsistent with GATT Article III (National Treatment) or Article XI (Quantitative Restrictions). The TRIMS illustrative list of prohibited measures covers local content, export performance, and foreign exchange limit and makes no mention of technology transfer. It was noted that the USA originally sought broader disciplines on performance requirements, including technology transfer requirements, but this position did not receive general support. ${ }^{61}$

\section{GATS}

In contrast to TRIMS, GATS addresses investment issues by liberalizing FDI in service sectors. Under mode 3 (the supply of services through commercial presence in the host country), ${ }^{62}$ each WTO member undertakes specific liberalization commitments as inscribed in its GATS Schedule. Unless otherwise noted in its Schedule, a member is obligated to (i) open all domestic service sectors to FDI, including eliminating foreign ownership restrictions (market-access commitments), and (ii) grant national treatment to foreign investors in respect of all measures affecting the supply of such services (national-treatment commitments). The extent of these commitments varies from member to member, depending on the results of their original negotiations.

Without mentioning technology transfer explicitly, GATS can nonetheless regulate mandatory technology transfer in two ways. One is through the elimination of ownership restrictions. Under Article XVI, a member shall not maintain equity limitations on foreign capital in sectors where it has made market-access commitments, unless otherwise specified in its Schedule. ${ }^{63}$ Thus, GATS limits the instances of technology transfer via ownership restrictions, including JV requirements, to the explicitly scheduled conditions to the market-access commitments of each member. The other way for GATS to regulate mandatory technology transfer is through the national-treatment commitments under Article XVII. Requiring foreign investors to transfer technology may violate such commitments, unless otherwise specified in the relevant Schedule. This understanding is reflected, for example, in the Schedule of India, where India inscribed a horizontal condition to mode 3 national treatment with respect to its

61 See Michael J. Trebilcock and Robert Howse, The Regulation of International Trade, $2^{\text {nd }}$ ed., (London: Routledge, 1999) 352.

62 GATS, art. I:2(c).

63 GATS, art. XVI:2(e) and (f). 
policy of giving preference to foreign entities that 'offer the best terms for transfer of technology. ${ }^{64}$ It is also worth noting that in its bid to join the WTO, China originally reserved the right to require foreign providers to transfer technology in two specific sectors in its GATS schedule, ${ }^{65}$ but its final Schedule no longer contains such entries.

\section{China's accession protocol}

Unlike other WTO members, China is bound by a special obligation regarding mandatory technology transfer under its accession protocol. Specifically, the protocol requires China to ensure that any government approval of foreign investment is not conditioned upon 'performance requirements of any kind, such as local content, offsets, the transfer of technology, export performance or the conduct of research and development in China. ${ }^{66}$ This broad requirement goes well beyond TRIMS, hence is one of the WTOplus obligations of China. ${ }^{67}$ As noted above, this China-specific obligation has given rise to EU's formal WTO complaint against China. ${ }^{68}$

In sum, international regulation of technology transfer is rather porous. With respect to technology transfer as a performance requirement, only a limited number of countries have undertaken to eliminate it under FTAs, and only China has undertaken the same within the WTO framework. As for technology transfer via mandatory JVs, it is constrained only to the extent of specific undertakings under FTAs or GATS mode 3. Instead of outright prohibition, the FTAs and GATS have treated foreign ownership restrictions as a matter of market access, subject to negotiated extent of national treatment.

\section{MARKET FOR TECHNOLOGY: A NORMATIVE PERSPECTIVE}

Requiring technology transfer in foreign investment, whether implemented through administrative means or ownership restrictions, is in essence a policy of market for technology. As discussed above, international regulation in this regard is far from uniform or consistent. While compelling technology transfer through administrative means has been outlawed by certain FTAs, mandatory JVs remain by and large a valid means of acquiring foreign technology. In practice, foreign ownership restrictions are fairly common; ${ }^{69}$ and a number of countries have adopted policies similar to those

64 GATS/SC/42. I am indebted to Ruosi Zhang for this understanding and for the India example.

65 They were 'advertising services' under mode 3 Market Access (requiring foreign providers to provide advanced technology as a condition to form joint ventures), and 'onshore oilfield services' under mode 3 National Treatment (requiring foreign providers to transfer technology to Chinese personnel). GATS/SC/19 (15 April 1994).

66 Supra note 36. This obligation is further elaborated in WPR, supra note 17, para 203.

67 See generally Julia Ya Qin, 'WTO-Plus' Obligations and Their Implications for the WTO Legal System: An Appraisal of the China Accession Protocol', 37 Journal of World Trade 483 (2003).

68 See supra note 7.

69 UNCTAD, World Investment Report 2018, p. 153 (finding that JV requirements remain common in many countries, especially in resource sectors and sectors with a public service responsibility, but have become rare in manufacturing and adjacent services industries, and that equity requirements are difficult to implement for countries that have small domestic markets or are part of a common market). 
in China. ${ }^{70}$ The US-China trade war, however, is challenging the legitimacy of this policy tool.

Hence the normative question: Is the policy of market for technology a legitimate tool for economic and technological development, and why? Addressing this question is critically important, not only because it is necessary for the resolution of US-China trade conflicts, but also because it will implicate the development strategies of many other countries.

A widely held view in China sees the market-for-technology policy as a perfectly legitimate tool for economic development. In this view, the policy embodies a fair exchange of economic opportunities, because all foreign firms come to China voluntarily and they will not do so without calculating the potential benefit of entering the Chinese market against the cost of losing certain technologies to the Chinese. Moreover, the policy does not require a free transfer of technology — foreign firms get paid for their technologies based on negotiated terms. Furthermore, the policy is not inconsistent with international legal norms, as free market access for foreign investment is not a given and must be negotiated on a case-by-case basis.

In the view of Western critics, however, the transfer of technology compelled by the market-for-technology policy is not truly 'voluntary' in nature, but rather the outcome of 'a de facto cartel' organized by the Chinese government, in which 'Chinese purchasers collude to expropriate key technologies' from foreign suppliers. ${ }^{71}$ According to this view, the practice amounts to unfair competition in the marketplace. From the perspective of economic theory, when China demands a tradeoff between market access and technology transfer, it behaves as monopsony, that is, it has the power of a single buyer with a substantial control over the market in which there are many would-be foreign sellers. Like monopoly power on the supply side, monopsony power on the demand side can produce economic harm. Where there is monopsony, the price of input tends to be depressed below the competitive level, resulting in a decrease in the overall quantity of the input produced. Thus, the market-for-technology policy may have deterred foreign firms from investing or operating in China at the optimal level. In the long run, the policy may also harm the broader global economy in that it may tilt the playing field in favor of less innovative Chinese firms in the global technology market, thereby limiting the resources flowing to the world's most innovative firms. ${ }^{72}$

To summarize, the prevailing view in China sees the tradeoff between market access and technology transfer as a fair exchange because the choice is to be made by the free will of market participants. This view is based on the assumption that market access is not a given. Western critics, on the other hand, seem to assume that market access

70 See Robert D. Atkinson, Hearing on 'The Impact of International Technology Transfer on American Research and Development' Before the House Science Committee Subcommittee on Investigations and Oversight of U.S. House of Representatives (5 December 2012) (identifying Portugal, Malaysia, Indonesia, Venezuela, and India as having adopted similar market-for-technology policies).

71 Lee G. Branstetter, 'China's Forced Technology Transfer Problem-And What to Do About It', PIIE Policy Brief 18-13 (June 2018), at 3.

72 Id., at 3-4. See also Thomas J. Holms, Ellen R. McGrattan and Edward C. Prescott, 'Quid Pro Quo: Technology Capital Transfers and Market Access in China', 82 The Review of Economic Studies 1154 (2015). 
should in principle be free from government intervention. Based on this assumption, the exchange between market access and technology transfer is fundamentally unfair. The economic theory of monopsony supports this view in that it depicts the China situation as one in which numerous would-be foreign sellers must deal with the Chinese government that acts as a single buyer due to its control over market access.

In the view of this author, the theory of government monopsony is valid, but its validity may have to be discounted when applied to the situation involving technology transfer. That is because the would-be foreign sellers, as the holders of related IP rights, enjoy state-granted monopoly over their IP-protected technologies. Monopoly is anticompetition in nature. Domestic and international regimes have long been concerned with the issue of how to strike a proper balance between the protection of IP rights and the need to prevent abusive practice of IP holders. ${ }^{73}$ Given such concerns, when government monopsony confronts IP monopolies, it is possible that their anticompetitive effects may offset each other at least to some extent.

Ultimately, the question of whether 'market for technology' represents a fair exchange cannot be answered in absolute terms. Rather, the answer may depend on the relative level of economic and technological development in the country in question. Take China as example. When it first adopted the market-for-technology policy nearly four decades ago, China was an economic and technological backwater. The types of foreign technology it could effectively absorb were not the most advanced in any field. Under such circumstances, the government requirement that foreign firms bring in desirable technology in exchange for market access would not threaten their competitiveness. On the contrary, foreign firms would benefit from the dissemination of knowledge in China, as it enabled the Chinese to become more efficient and sophisticated producers in the global supply chains led by the technologically advanced firms. Fast forward to the second decade of the 21st century, China has transformed itself into the world's second largest economy, capable of absorbing cutting-edge technologies in any field. Some Chinese firms have emerged as global leaders and many as formidable competitors of foreign firms. Under these circumstances, 'market for technology', enforced by the government through administrative means or ownership restrictions, can no longer be deemed a fair exchange. When China becomes capable of competing with others on an equal footing, such government intervention will result in creating an unfair advantage for Chinese firms at the expense of foreign competitors. That is also why the issue of forced technology transfer did not come to the fore until more recent years, even though China's market-for-technology policy had existed for decades. Fairness requires the similarly situated to be treated similarly. Imagine if the EU, Japan, or South Korea were to adopt such a policy, would it be considered fair play?

At this juncture, it is necessary to consider China's status as a developing country. Under the world trading system, developing countries are entitled to special and differential treatment (S\&D), which generally translates into more policy space and fewer commitments in trade and investment liberalization. Except for 'the least-developed

73 See generally Keith Maskus, Private Rights and Public Problems: The Global Economics of Intellectual Property in the 21st Century (Washington, D.C.: Peterson Institute for International Economics, 2010). 
countries' (LDCs), the developing country status within the WTO is based on selfdeclaration. ${ }^{74}$ In its WTO accession, China was treated as a developing country in principle but was denied certain S\&D. ${ }^{75}$ The average of China's import tariff bindings on industrial products was about $10 \%$, which was significantly higher than the average of $3 \%-4 \%$ for developed countries, but much lower than other large countries such as India and Brazil, which maintained average tariff bindings around 30\%. ${ }^{76}$

Despite the dramatic rise in its economic power, China refuses to give up its developing country status. ${ }^{77}$ Insisting on China being the largest developing country has become a political mantra of Beijing. It is true that China's GDP per capita remains well below the average of OECD countries and that about 30 million Chinese still live below the poverty line. ${ }^{78}$ However, what matters most to the rest of the world is China's 'comprehensive national power,' a concept developed by the Chinese themselves. ${ }^{79}$ When considering the aggregate of a variety of factors, including economic power, science and technology, education, territory, natural resources, population, military force, and domestic governance, China is clearly a contemporary superpower. Consequently, there is little reason why China should not be treated as an equal of the OECD countries when it comes to the policy of technology transfer and market access. In this regard, it should be noted that the USA is challenging the practice of self-declared development status at the WTO, and the issue is poised to be a major item on the WTO-reform agenda. ${ }^{80}$

\section{INTERNATIONAL REGULATION OF FORCED TECHNOLOGY TRANSFER: A PROPOSAL}

In light of the above analysis, the key to international regulation of forced technology transfer lies in the differentiation of levels of economic and technological development of the prospective technology-receiving countries. ${ }^{81}$ As shown in the case of China, when the country is at a relatively low level of economic and technological development,

74 Marrakesh Agreement Establishing the World Trade Organization (WTO Agreement), art. XI:2, recognizes the category of LDCs by the UN criteria.

75 For example, China may not invoke certain provisions of Article 27 of the Agreement on Subsidies and Countervailing Measures (SCM) that provide S\&D to developing countries. On agriculture subsidies, China was granted a de minimis level of $8.5 \%$, which was higher than the $5 \%$ level for developed countries but below the $10 \%$ level for developing countries specified in Article 6.4 of the Agreement on Agriculture. See WPR, supra note 17, paras 171-74, 235.

76 Nicholas Lardy, Integrating China into the Global Economy (Washington, D.C.: Brookings Institution Press, 2002) 79.

77 Wang Shouwen, Vice Minister of Commerce, declared at the MOFCOM press briefing on the issues of WTO reform in November 2018: 'We do not allow other members to deprive China of the special and differential treatment of developing members that we deserve.' http://english.mofcom.gov.cn/article/newsrelease/ press/201811/20181102810628.shtml.

78 See World Bank, https://databank.worldbank.org/data/download/poverty/33EF03BB-9722-4AE2ABC7-AA2972D68AFE/Archives-2019/Global_POVEQ_CHN.pdf.

79 Michael Pillsbury, China Debates the Future Security Environment (Washington, D.C.: National Defense University Press, 2000), ch. 5 (discussing the Chinese origin of the concept).

80 WTO, Communication from the United States: An Undifferentiated WTO: Self-Declared Development Status Risks Institutional Irrelevance, WT/GC/W/757, 16 January 2019) ('The US Initiative on Development Status').

81 It has been suggested that on the transfer of technology to developing countries, generally, a countrydifferentiation approach is needed for policy and multilateral rulemaking. Hoekman et al., supra note 60 . 
government policy requiring foreign firms to share technology in exchange for market access may result in a mutually beneficial situation. Yet, when the country reaches a certain level of technological capacity and its domestic entities emerge as potential competitors to the foreign firms, it becomes unfair and even harmful to allow the government to pursue the same market-for-technology policy, as such a policy will create unfair advantages for its domestic firms, resulting in unfair competition in international trade and investment.

Accordingly, international regulation should not seek to impose an outright ban on the market-for-technology exchange. Instead, it should recognize as a matter of principle: (i) the market-for-technology policy adopted by poor countries could enhance the positive spillover effect of knowledge dissemination without causing unfair competition in the market, hence could be a legitimate tool of economic development; and (ii) the policy would constitute an unfair practice when adopted by countries with a certain level of economic and technological capacity. Following this principle, it will be necessary, first, to have a country-classification system, then a discipline on the unfair practice.

How can we design a country-classification system capable of differentiating among countries with different levels of economic and technological development? Admittedly, the task would be highly challenging both politically and technically. That said, there could be some synergy between this proposal and the broader US initiative on differentiation of development levels among WTO members. ${ }^{82}$ As noted by the USA, international organizations have had years of experience in classifying economies. The World Bank, for instance, divides countries into four groups based on gross national income (GNI) per capita (low income, lower-middle income, upper-middle income, and high income) and adjusts the income thresholds each year in line with price inflation. Currently, the high-income group includes 80 countries, and the upper-middle income group 60 countries covering notably China, Brazil, Mexico, Turkey, and South Africa. ${ }^{83}$

More significantly, a number of institutions have created indices to measure technological and innovation capabilities at the country level. ${ }^{84}$ While differing in their methodologies and coverage, these indices 'tend to measure in different ways the same factors' such as human capital, infrastructure, public and private research expenditure, and innovation outputs such as patents and publications, and 'the country-rankings

82 The US Initiative on Development Status, supra note 80, at 8-10. Significantly, the US Initiative has received a positive response from Brazil, which has agreed to forgo special and differential treatment in WTO negotiations. See Joint Statement from President Donald J. Trump and President Jair Bolsonaro (19March 2019), https://www.whitehouse.gov/briefings-statements/joint-statement-president-donald-jtrump-president-jair-bolsonaro/.

83 See World Bank, https://datahelpdesk.worldbank.org/knowledgebase/articles/906519-world-bankcountry-and-lending-groups.

84 See UNCTAD, Transfer of Technology and Knowledge Sharing for Development (2014), 7 (identifying the Innovation Capability Index by UNCTAD, the Technology Achievement Index by UNDP, the Global Competitive Index by the World Economic Forum, the Knowledge Economy Index by the World Bank, the Summary Innovation Index by the EU Commission, and the Global Innovation Index by Connell University/INSEAD/WIPO). 
generated by these indicators present very high correlation coefficients. ${ }^{95}$ Take for example the Global Innovation Index (GII) co-published by Connell University, INSEAD and the World Intellectual Property Organization (WIPO). ${ }^{86}$ Currently in its 12th edition, the GII Report ranks innovation capabilities and performances of more than 120 economies each year. The GII scores are calculated on the basis of two sub-indices: the innovation input sub-index, which comprises five pillars that enable innovative activities - institutions, human capital and research, infrastructure, market sophistication, and business sophistication; and the innovation output sub-index, which calculates knowledge/technology and creative outputs, measured by patent applications, publications in peer-reviewed journals, high-tech net exports, mobile app creation, exports of cultural goods and services, increases in labor productivity, and many other factors. For the year of 2018, the GII top 10 are Switzerland, the Netherlands, Sweden, UK, Singapore, United States, Finland, Denmark, Germany, and Ireland; of the large developing countries, China ranked the 17th (above Canada (18th), Italy (31st), and Australia (20th)), Mexico 56th, India 57th, South Africa 58th, Brazil 64th, Argentina 80th, and Indonesia 85th. ${ }^{87}$

For our purposes, the most instructive findings of the GII 2018 report include the following: (i) there exists a positive link between innovation performance and an economy's level of development as measured by GDP per capita; (ii) country size (reflected by population size) is not correlated with the GII scores in a statistically significant way; and (iii) economies at all levels of development happen to be more innovative when they have a more diversified export portfolio. ${ }^{88}$ In light of these findings, the country-classification system for international regulation of technology transfer could be intelligently designed by reference to a combination of income-based rankings (GDP or GNI per capita) and the rankings by innovation indices, such as the GII scores.

It should be recognized, however, that technological capabilities tend to vary from sector to sector, and a country-based classification system may not be able to reflect such variances. Moreover, a country's technological capabilities are constantly changing, thus measuring such capabilities is necessarily a dynamic process. Given the imprecise nature of any country-classification scheme, the new discipline on technology transfer would need to have certain built-in flexibility.

It is suggested here that such flexibility could be achieved by following the model of GATS mode 3. As already discussed, GATS mode 3 contains market-access commitments of WTO members on FDI in service sectors. Unless otherwise specified in its GATS Schedule, a member may not impose equity restrictions, such as JV requirements, on FDI in any of the service sectors covered by GATS. The elimination of equity restrictions forestalls the possibility of compelled transfer of technology to local JV partners and gives the foreign investor a better control over its proprietary information. Under mode 3, a member is also required to accord national treatment

85 Id.

86 https://www.globalinnovationindex.org.

87 Global Innovation Index 2018, https://www.globalinnovationindex.org/gii-2018-report.

88 Id., no. 4 of the key findings. 
to foreign investors in respect of all measures affecting services, which include any requirement on technology transfer, unless otherwise specified in its Schedule. The limitations and conditions on market access and national treatment are agreed and specified in the Schedule of each member based on the result of multilateral negotiations. A member's Schedule may be modified and specific commitments withdrawn through renegotiations or otherwise as permitted under GATS Article XXI. In addition, all GATS commitments are subject to the general public policy and national security exceptions under Articles XIV and XIV bis.

For the new discipline on technology transfer, a similar approach could be adopted to cover both goods and services sectors. Thus, each member would make commitments not to impose ownership restrictions on foreign investment or otherwise impose requirements on technology transfer in each of the goods and services sectors, unless otherwise specified. However, as a matter of principle, countries that have reached a certain level of economic and technological capacity, as predetermined by the countryclassification system, would not be allowed to depart from those general commitments. Considering the inevitable variances in the technological capabilities of countries classified in the same category, the actual commitments of individual countries in specific sectors might differ depending on the results of multilateral negotiations. In addition, periodic renegotiations of the commitments should be scheduled, so as to be responsive to changes in the economic and technological capabilities of countries. Like GATS, all commitments under the technology-transfer discipline should be made subject to general public policy and security exceptions, thus safeguarding the legitimate interests of all countries involved.

\section{CONCLUSIONS}

The ongoing US-China trade war has given rise to the call for international regulation of 'forced technology transfer'. While lacking a precise definition, the term can be broadly understood as referring to a situation in which the government compels a foreign firm to share its proprietary technology as a condition for accessing its domestic market. The government may compel the disclosure of foreign propriety information through administrative processes, such as approvals and licensing requirements that are unnecessary for legitimate regulatory purposes. This type of practice amounts to disguised government expropriation of foreign IP rights in violation of well-established international norms, thus must be condemned. The government may also compel technology transfer via equity restrictions on foreign investment. Foreign ownership restrictions, however, are not generally prohibited by international law. In fact, they are commonly practiced. Hence, how to regulate such restrictions presents a major challenge.

In order to establish a new discipline on technology transfer, a threshold question must be answered: Is the market-for-technology exchange an unfair practice or a legitimate policy of economic development? To the extent that the government controls market access, it wields the power of a monopsony, which is anticompetitive by nature. This monopsony power, however, might be used to offset the anticompetitive effects of the monopoly power of IP owners, thereby promoting the dissemination of knowledge. 
As shown in the case of China, when the host country is at a relatively low level of economic and technological development, the market-for-technology policy tends to create a mutually beneficial situation for the host country and foreign investors. But as the country reaches a certain level of technological capabilities and its domestic firms become potential competitors of foreign firms, the market-for-technology policy can no longer be considered a fair practice.

Accordingly, this article proposes that international regulation should adopt a country-classification system capable of differentiating among countries with different levels of economic and technological development. Only countries that have reached a certain level of development would be prohibited from using ownership restrictions as a means to acquire foreign technology. Following the model of GATS mode 3, such prohibition could be negotiated and recorded on a country-specific basis as the marketaccess commitments in both goods and service sectors, subject only to public policy exceptions.

All positive change in the world begins with an idea. It is my hope that the proposal made in this article, no matter how unrealistic it may seem at the moment, will contribute to the eventual enactment of a new discipline that is capable of promoting wide dissemination of technology while ensuring fair competition in international trade and investment. 